\title{
DNA testing for variants conferring low or moderate increase in the risk of cancer
}

\author{
Grzegorz Kurzawski, Janina Suchy, Cezary Cybulski, Joanna Matyjasik, Tadeusz Dębniak, Bohdan Górski, Tomasz Huzarski, \\ Anna Janicka, Jolanta Szymańska-Pasternak, Jan Lubiński
}

International Hereditary Cancer Centre, Department of Genetics and Pathology, Szczecin, Poland

Corresponding author: International Hereditary Cancer Centre, Department of Genetics and Pathology, Pomeranian Medical University, ul. Połabska 4, 70-115 Szczecin, Poland

\section{DNA test based on analysis of 3020insC in NOD2 gene}

3020insC in the NOD2 gene increases the risk of:

- breast cancer DCIS below age 50 about 5-fold - this mutation is detected in $8 \%$ of all breast cancer cases,

- colorectal cancer approximately 2-fold above age 60 - this mutation is present in 15\% of all colorectal cancer cases,

- lung cancer about 2-fold - this mutation is present in $12 \%$ of all lung cancer cases,

- ovarian cancer about 1.5-fold - this mutation is present in $11 \%$ of all ovarian cancer cases [1, 2].

Surveillance for carriers of 3020insC in NOD2 gene recommended as an option:

Recommendations for women:

- breast self-examination,

- breast examination by doctor from age $20,1 \times 6$ months,

- breast USG from age 20, $1 \times$ year,

- mammography from age 35, 1 × year, alternately with breast USG,

- intravaginal USG from age 45, $1 \times$ year,

- colonoscopy or barium enema age 60, every 5 years or more often in case of intestinal abnormalities,

- smoking forbidden, diet richer in fruits and vegetables.

Recommendations for men:

- colonoscopy or barium enema age 60, every 5 years or more often in case of any intestinal abnormalities,

- smoking forbidden, diet richer in fruits and vegetables.

\section{DNA test based on analysis of 1100 delC, IVS2+1G >A, del5395, I157T mutations in CHEK2 gene}

CHEK2 protein truncating mutations (1 100delC, IVS2 + 1G>A, del5395) increase the risk of:
- breast cancer about 2.4-fold - these mutations are present in about $2.5 \%$ of all breast cancer cases,

- prostate cancer about 2.3-fold - these mutations are present in about $2.5 \%$ of all prostate cancer cases and about $5 \%$ of familial prostate cancer cases; the risk is increased about 5-fold if prostate cancer is present in at least one first degree relative,

- papillary thyroid cancer - about 5-fold - these mutations are present in about $4 \%$ of all papillary thyroid cancer cases [3-5].

Missense mutation $1157 \mathrm{~T}$ in the CHEK2 gene increases the risk of:

- breast cancer (more commonly lobular subtype) about 1.5-fold - this mutation is present in about 7\% of all breast cancer cases,

- prostate cancer about 1.6-fold - this mutation is present in about $8 \%$ of all prostate cancer cases and about $12 \%$ of familial prostate cancer cases; the risk is increased about 3-fold if prostate cancer is present in at least one first degree relative,

- papillary thyroid cancer - about 2-fold - this mutation is present in about $9 \%$ of all papillary thyroid cancer cases,

- kidney cancer - about 2-fold - this mutation is present in about $10 \%$ of all kidney cancer cases,

- colorectal cancer - about 2-fold - this mutation is present in about 10\% of colorectal cancer cases [2-4],

- ovarian cancer of low-grade about 2-fold - this mutation is present in about $10 \%$ of ovarian cancer cases G1; and ovarian epithelial tumours of borderline malignancy about 2.5-fold - this mutation is present in about $11.5 \%$ of ovarian cancer cases of borderline malignancy [6].

Surveillance for carriers of protein truncating mutations of CHEK2 (1100delC, IVS2+1G>A, del5395) recommended as an option: 
Recommendations for women:

- breast self-examination,

- breast examination by doctor from age $25,1 \times 6$ months,

- breast USG from age 25, $1 \times$ year,

- mammography from age 35, 1 × year, alternately with breast USG,

- thyroid USG from age 20, $1 \times$ year.

Recommendations for men:

- digital rectal examination of prostate, PSA from age 50, $1 \times$ year,

- consideration of saturation biopsy of prostate after age 60 - in case of a positive family history of prostate cancer in a first degree relative.

Surveillance for carriers of CHEK2 I157T missense mutation recommended as an option:

Recommendations for women:

- breast self-examination,

- breast examination by doctor from age 40, $1 \times 6$ months,

- breast USG from age 40, $1 \times$ year,

- MRI or mammography from age 40, 1 × year, alternately with breast USG,

- intravaginal USG from age 25, $1 \times$ year,

- abdominal USG from age 40, $1 \times$ year,

- colonoscopy or barium enema from age 60, every 5 years or more often in case of intestinal abnormalities,

- thyroid USG from age 20, $1 \times$ year.

Recommendations for men:

- abdominal USG from age 40, $1 \times$ year,

- colonoscopy or barium enema from age 60, every 5 years or more often in case of intestinal abnormalities,

- digital rectal examination of prostate, PSA from age 50, $1 \times$ year,

- consideration of saturation biopsy of prostate after age 60 - in case of a positive family history of prostate cancer in a first degree relative.

\section{DNA test based on analysis of 657del5 mutation in NBS1 gene}

Mutation 657 del5 in the NBS 1 gene increases the risk of:

- breast cancer about 2-fold - this mutation is present in about $1 \%$ of all breast cancer cases,

- prostate cancer about 4-fold - this mutation is present in about $3 \%$ of all prostate cancer cases and about $9 \%$ of familial prostate cancer cases; the risk is increased about 15 -fold if prostate cancer is present in at least one first degree relative [7].

Surveillance for carriers of NBS1 657 del5 mutation recommended as an option:

Recommendations for women:

- breast self-examination,

- breast examination by doctor from age 30, $1 \times 6$ months,

- breast USG from age 30, 1 × year,

- mammography from age 30, 1 × year, alternately with breast USG.

Recommendations for men:

- digital rectal examination of prostate, PSA from age 50, $1 \times$ year

- consideration of saturation biopsy of prostate after age 60 - in case of a positive family history of prostate cancer in a first degree relative.

\section{DNA test based on analysis of A148T variant of CDKN2A (p16) gene}

A 148T in the CDKN2A gene increases the risk of:

- malignant melanoma - about 2-fold - this mutation is present in about $7 \%$ of all melanoma cases,

- breast cancer (more commonly DCIS) about 1.5-fold - this mutation is present in about $5 \%$ of all breast cancer cases,

- colorectal cancer - about 1.5-fold - this mutation is present in about $5 \%$ of all colorectal cancer cases,

- lung cancer - about 2-fold - this mutation is present in about $7 \%$ of all lung cancer cases [8-10].

Surveillance for carriers of CDKN2A A148T mutation recommended as an option:

Recommendations for women:

- breast self-examination,

- breast examination by doctor from age 20, $1 \times 6$ months,

- breast USG from age 20, $1 \times$ year,

- mammography from age 35, 1 × year, alternately with breast USG,

- colonoscopy or barium enema from age 60, every 5 years or more often in case of intestinal abnormalities,

- smoking forbidden, diet rich in fruits and vegetables,

- the use of high sun protection factor sunscreens (30 or more), avoidance of physical trauma of nevi, 
- in cases with moles showing clinical signs of malignant transformation (increase of size, red hue, bleeding, pruritus) immediate consultation by dermatologist or oncologist.

Recommendations for men:

- colonoscopy or barium enema from age 60, every 5 years or more often in case of intestinal abnormalities,

- smoking forbidden, diet rich in fruits and vegetables,

- the use of high sun protection factor sunscreens (30 or more), avoidance of physical trauma of nevi,

- in cases with moles showing clinical signs of malignant transformation (increase of size, red hue, bleeding, pruritus) immediate consultation by dermatologist or oncologist.

\section{DNA test based on analysis of variants C142G, G355T, G4326C of CYP1B1 gene}

Homozygous carriers of variants C142G, G355T, G4326C (homozygotes GTC) of the CYP1B1 gene are at 2-fold increased risk of breast cancer. This genotype is present in about $12 \%$ of breast cancer cases [11].

Surveillance recommended as an option for women with homozygous GTC genotype in CYP1B 1 gene:

- breast self-examination,

- breast examination by doctor from age $25,1 \times 6$ months,

- breast USG from age 25, 1 × year,

- MRI or mammography from age 25-30, 1 × year, alternately with breast USG.

\section{DNA test based on analysis of C5972T variant of BRCA2 gene}

C5972T variant in the BRCA2 gene increases the risk of breast cancer with DCIS below age 50 about 3-fold; homozygous carriers of this variant (homozygotes TT) are at about 5-fold increased risk of breast cancer below age 50; this variant is present in about $6 \%$ of breast cancer cases below age 50 [12].

Surveillance recommended as an option for carriers of C5972T variant:

- breast self-examination,

- breast examination by doctor from age $25,1 \times 6$ months,

- breast USG from age 25, $1 \times$ year,

- mammography from age 35, 1 × year, alternately with breast USG.

\section{DNA test based on analysis of C61G and 4153delA mutations in BRCA1 gene in men}

C61G and 4153delA mutations in the BRCA1 gene increase the risk of prostate cancer about 3.6-fold these mutations are present in about $0.4 \%$ of all prostate cancer cases; the risk is increased about 12-fold if prostate cancer is present in at least one first degree relative [13].

Surveillance recommended as an option for men with C61G or 4153 delA mutation:

- digital rectal examination of prostate, PSA from age $50,1 \times$ year,

- consideration of saturation biopsy of prostate after age 60 - in case of a positive family history of prostate cancer in a first degree relative.

\section{References}

1. Kurzawski G, Suchy J, Kładny J, Grabowska E, Mierzejewski M, Jakubowska A, Debniak T, Cybulski C, Kowalska E, Szych Z, Domagała W, Scott RJ, Lubiński J. The NOD2 3020insC mutation and the risk of colorectal cancer. Cancer Res 2004; 64: 1604-1606.

2. Lubinski J, Huzarski T, Kurzawski G, Suchy J, Masoic B, Mierzejewski M, Lener M, Domagala W, Chosia M, Teodorczyk U, Medrek K, Debniak T, Zlowocka E, Gronwald J, Byrski T, Grabowska E, Nej K, Szymanska A, Szymanska J, Matyjasik J, Cybulski C, Jakubowska A, Gorski B, Narod SA. The 3020insC allele of NOD2 predisposes to cancers of multiple organs. Hered Caner Clin Pract 2005; 3: 59-63.

3. Cybulski C, Górski B, Huzarski T, Masojć B, Mierzejewski M, Debniak T, Teodorczyk U, Byrski T, Gronwald J, Matyjasik J, Zlowocka E, Lenner M, Grabowska E, Nej K, Castaneda J, Medrek K, Szymańska A, Szymańska J, Kurzawski G, Suchy J, Oszurek O, Witek A, Narod SA, Lubiński J. CHEK2 is a multiorgan cancer susceptibility gene. Am J Hum Genet 2004; 75: 1131-1135.

4. Cybulski C, Wokołorczyk D, Huzarski T, Byrski T, Gronwald J, Górski B, Debniak T, Masojć B, Jakubowska A, Gliniewicz B, Sikorski A, Stawicka M, Godlewski D, Kwias Z, Antczak A, Krajka K, Lauer W, Sosnowski M, Sikorska-Radek P, Bar K, Klijer R, Zdrojowy R, Małkiewicz B, Borkowski A, Borkowski T, Szwiec M, Narod SA, Lubiński J. A large germline deletion in the CHEK2 kinase gene is associated with an increased risk of prostate cancer. J Med Genet 2006; 43: 863-866.

5. Cybulski C, Wokołorczyk D, Huzarski T, Byrski T, Gronwald J, Górski B, Debniak T, Masojć B, Jakubowska A, van de Wetering T, Narod SA, Lubiński J. A deletion in CHEK2 of 5,395 bp predisposes to breast cancer in Poland. Breast Cancer Res Treat 2007; 102: 119-122.

6. Szymanska-Pasternak J, Szymanska A, Medrek K, Imyanitov EN, Cybulski C, Gorski B, Magnowski P, Dziuba I, Gugala K, Debniak B, Gozdz S, Sokolenko AP, Krylova NY, Lobeiko OS, Narod SA, Lubinski J. CHEK2 variants predispose to benign, borderline and low-grade invasive ovarian tumors. Gynecol Oncol 2006; 102: 429-431.

7. Cybulski C, Górski B, Debniak T, Gliniewicz B, Mierzejewski M, Masoić B, Jakubowska A, Matyjasik J, Złowocka E, Sikorski A, 
Narod SA, Lubiński J. NBS1 is a prostate cancer susceptibility gene. Cancer Res 2004; 64: 1215-1219.

8. Debniak T, Scott RJ, Huzarski T, Byrski T, Rozmiarek A, Debniak B, Załuga E, Maleszka R, Kładny J, Górski B, Cybulski C, Gronwald J, Kurzawski G, Lubinski J. CDKN2A common variants and their association with melanoma risk: a population-based study. Cancer Res 2005; 65: 835-839.

9. Debniak T, Górski B, Huzarski T, Byrski T, Cybulski C, Mackiewicz A, Gozdecka-Grodecka S, Gronwald J, Kowalska E, Haus O, Grzybowska E, Stawicka M, Swiec M, Urbański K, Niepsuj S, Waśko B, Góźdź S, Wandzel P, Szczylik C, Surdyka D, Rozmiarek A, Zambrano O, Posmyk M, Narod SA, Lubinski J. A common variant of CDKN2A (p 16) predisposes to breast cancer. J Med Genet 2005; 42: 763-765.

10. Debniak T, Scott RJ, Huzarski T, Byrski T, Rozmiarek A, Debniak B, Górski B, Cybulski C, Medrek K, Mierzejewski M, Masojc B, Matyjasik J, Złowocka E, Teodorczyk U, Lener M, KlujszoGrabowska E, Nej-Wołosiak K, Jaworowska E, Oszutowska D, Szymańska A, Szymańska J, Castaneda J, van de Wetering T, Suchy J, Kurzawski G, Oszurek O, Narod S, Lubinski J. CDKN2A common variant and multi-organ cancer risk-a population-based study. Int J Cancer 2006; 118: 3180-3182.

11. Matyjasik J, Cybulski C, Masojć B, Jakubowska A, SerranoFernandez P, Górski B, Debniak T, Huzarski T, Byrski T, Gronwald J, Złowocka E, Narod SA, Scott R, Lubinski J. CYPlBl and predisposition to breast cancer in Poland. Breast Cancer Res Treat 2007; 106: 383-388.

12. Górski B, Narod SA, Lubinski J. A common missense variant in BRCA2 predisposes to early onset breast cancer. Breast Cancer Res 2005; 7: R1023-R1027.

13. Cybulski C, Górski B, Gronwald J, Huzarski T, Byrski T, Debniak T, Jakubowska A, Wokołorczyk D, Gliniewicz B, Sikorski A, Stawicka M, Godlewski D, Kwias Z, Antczak A, Krajka K, Lauer W, Sosnowski M, Sikorska-Radek P, Bar K, Klijer R, Romuald Z, Małkiewicz B, Borkowski A, Borkowski T, Szwiec M, Posmyk M, Narod SA, Lubiński J. BRCA1 mutations and prostate cancer in Poland. Eur J Cancer Prev 2008; 17: 62-66. 